\title{
Ceramic water filter for point-of-use water treatment in developing countries: Principles, challenges and opportunities
}

\author{
Haiyan Yang ${ }^{1,2}$, Shangping $\mathrm{Xu}^{3}$, Derek E. Chitwood ${ }^{4}$, Yin Wang $(\bowtie)^{5}$ \\ 1 SCNU Environmental Research Institute, Guangdong Provincial Key Laboratory of Chemical Pollution and Environmental Safety \& MOE Key \\ Laboratory of Theoretical Chemistry of Environment, South China Normal University, Guangzhou 510006, China \\ 2 School of Environment, South China Normal University, University Town, Guangzhou 510006, China \\ 3 Department of Geosciences, University of Wisconsin-Milwaukee, Milwaukee, WI 53211, USA \\ 4 Department of Engineering, Dordt University, Sioux Center, IA 51250, USA \\ 5 Department of Civil and Environmental Engineering, University of Wisconsin-Milwaukee, Milwaukee, WI 53211, USA
}

\section{H I G H L I G H T S}

- $\mathrm{CWF}$ is a sustainable POU water treatment method for developing areas.

- CWF manufacturing process is critical for its filtration performance.

- Simultaneous increase of flow rate and pathogen removal is a challenge.

- Control of pore size distribution holds promises to improve CWF efficiency.

- Novel coatings of CWFs are a promising method to improve contaminant removal.

\section{A R T I C L E I N F O}

\section{Article history:}

Received 14 January 2020

Revised 18 March 2020

Accepted 21 March 2020

Available online 16 May 2020

Keywords:

Point-of-use water treatment

Ceramic water filter

Bacterial removal

Surface modification

Water quality

\section{GRAPHIC A B T RACT}
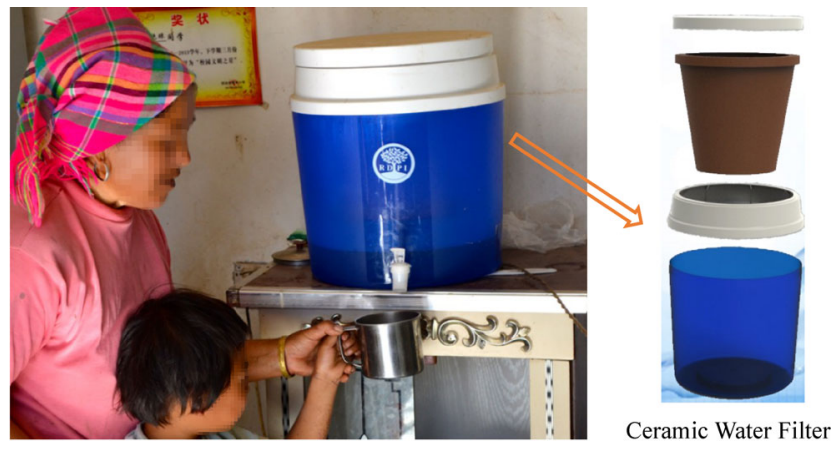

\section{A B S T R A C T}

Drinking water source contamination poses a great threat to human health in developing countries. Point-of-use (POU) water treatment techniques, which improve drinking water quality at the household level, offer an affordable and convenient way to obtain safe drinking water and thus can reduce the outbreaks of waterborne diseases. Ceramic water filters (CWFs), fabricated from locally sourced materials and manufactured by local labor, are one of the most socially acceptable POU water treatment technologies because of their effectiveness, low-cost and ease of use. This review concisely summarizes the critical factors that influence the performance of CWFs, including (1) CWF manufacturing process (raw material selection, firing process, silver impregnation), and (2) source water quality. Then, an in-depth discussion is presented with emphasis on key research efforts to address two major challenges of conventional CWFs, including (1) simultaneous increase of filter flow rate and bacterial removal efficiency, and (2) removal of various concerning pollutants, such as viruses and metal(loid)s. To promote the application of CWFs, future research directions can focus on: (1) investigation of pore size distribution and pore structure to achieve higher flow rates and effective pathogen removal by elucidating pathogen transport in porous ceramic and adjusting manufacture parameters; and (2) exploration of new surface modification approaches with enhanced interaction between a variety of contaminants and ceramic surfaces.

(C) The Author(s) 2020. This article is published with open access at link.springer.com and journal.hep. com.cn 2020

\section{Introduction}

$凶$ Corresponding author

E-mail: wang292@uwm.edu

Special Issue-Accounts of Aquatic Chemistry and Technology Research (Responsible Editors: Jinyong Liu, Haoran Wei \& Yin Wang)
World Health Organization (WHO) reported that $71 \%$ of the world's population used improved drinking water 
sources that were free from microbiological and priority chemical contamination in 2017 (World Health Organization, 2017,2019a). However, there are vast inequalities among different countries and areas. For example, although $85 \%$ of world urban population could access quality drinking water that is free from contamination, the percentage is down to $53 \%$ in rural areas. A large effort is still needed in rural areas, especially in developing countries where pathogen contamination of drinking water represents one of the greatest threats to human health (World Health Organization, 2019b). What's worse, in developing areas such as sub-Saharan Africa, Central and Southern Asia and Oceania, centralized water treatment and distribution systems are often unavailable due to political or socioeconomic factors (Peter-Varbanets et al., 2009; World Health Organization, 2019a). In these areas, point-of-use (POU) systems, which improve drinking water quality at the household level, represent a more affordable and effective way to produce water free from contamination.

In practice, a POU technology should be effective, easy to operate, with low maintenance requirement, economically viable, environmentally sustainable and socioculturally acceptable. Chlorination with safe storage, combined coagulant-chlorine disinfection systems, solar disinfection, ceramic water filter (CWF) and biosand filter are examples of current POU technologies (Sobsey et al., 2008; Murphy et al., 2010; Kallman et al., 2011; Geremew et al., 2018). Based on a comprehensive comparison of these technologies (Table 1), CWF is considered among the most practical and sustainable POU technologies with affordable (highly cost effective) and low-maintenance (easy to use, only periodic cleaning needed) features for household water treatment in developing countries (Sobsey et al.,
2008; Clasen et al., 2015). CWFs, produced from a mixture of clay and sieved combustible material, can effectively remove microorganisms and reduce turbidity from water by gravity filtration through porous ceramic media. CWFs can be fabricated into different shapes, such as disk, tube, candle and pot (Fig. 1), which make them suitable for POU application in various situations. Silver impregnation has been conventionally applied to modify CWFs to enhance their performance, particularly for the removal of microorganisms. Silver-modified CWFs are effective at remov-

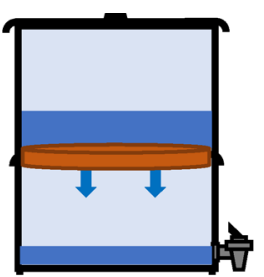

(a)

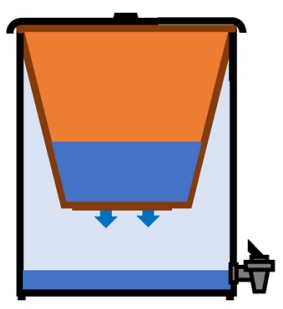

(c)

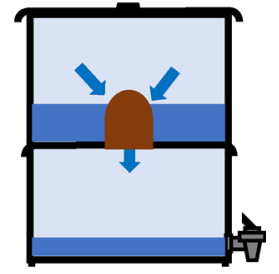

(b)

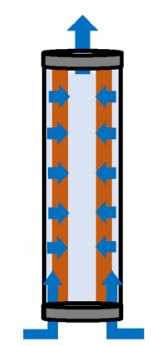

(d)
Fig. 1 Schematic of different forms of ceramic water filters: (a) ceramic disk filter, (b) ceramic candle filter, (c) ceramic pot filter, (d) tubular ceramic filter.

Table 1 Comparison of POU treatment technologies used in developing countries ${ }^{\text {a) }}$

\begin{tabular}{|c|c|c|c|c|c|c|}
\hline $\begin{array}{l}\text { POU } \\
\text { technologies }\end{array}$ & $\begin{array}{c}\text { Water } \\
\left.\text { quality }{ }^{b}\right)\end{array}$ & $\begin{array}{c}\text { Water } \\
\left.\text { production }^{\mathrm{c}}\right)\end{array}$ & $\operatorname{Cost}^{\mathrm{d})}$ & Ease to use ${ }^{\mathrm{e})}$ & $\begin{array}{c}\text { Overall } \\
\text { score }\end{array}$ & Description \\
\hline Chlorination & 1 & 3 & 2 & 5 & 11 & $\begin{array}{l}\text { Hypochlorite liquid or tablets are used to inactivate } \\
\text { pathogens in source water. }\end{array}$ \\
\hline $\begin{array}{l}\text { Coagulation/ } \\
\text { Chlorination }\end{array}$ & 2 & 2 & 1 & 2 & 7 & $\begin{array}{c}\text { Dry coagulant-flocculant and chlorine as tablets or sachets } \\
\text { are added to source water to inactive and settle down } \\
\text { pathogens. }\end{array}$ \\
\hline $\begin{array}{l}\text { Solar disinfec- } \\
\text { tion }\end{array}$ & 3 & 1 & 5 & 1 & 10 & $\begin{array}{c}\text { Source water is filled in polyethylene terephthalate (PET) or } \\
\text { glass under sunlight, allowing UV and heat to inactivate } \\
\text { pathogens. }\end{array}$ \\
\hline $\begin{array}{l}\text { Ceramic water } \\
\text { filter }\end{array}$ & 5 & 2 & 4 & 4 & 15 & $\begin{array}{l}\text { Porous ceramic media (e.g., pot, disk, candle) with silver } \\
\text { coating is used to filter pathogens from source water. }\end{array}$ \\
\hline Biosand filter & 4 & 3 & 3 & 3 & 13 & $\begin{array}{c}\text { Biosand filter is adapted from slow sand filter cover with } \\
\text { biofilm, removing pathogens using biological and physical } \\
\text { processes. }\end{array}$ \\
\hline
\end{tabular}

Note: a) The scoring system was used to compare POU technologies. For each criterion, a technology was ranked from best (with a score of 5) to worst (with a score of 1) and the performance score ( 5 to 1 ) represents its relative ranking; b) This score was based on their reduction in Diarrhea reported by Clasen et al. (2015); c) Water production was scored based on producing $20 \mathrm{~L}$ within $4 \mathrm{~h}$ of applying the treatment described by Sobsey et al. (2008). Due to the different water production methods for these POU technology, the score was only set to 1-3 with 1 for low, 2 for fair, and 3 for good performance; d) This score was based on their cost (dollars/L/year) calculated in Sobsey et al. (2008); e) This score was based on the steps of treatment processes and periodic maintenance. 
ing $>99 \%$ of protozoan (Van Halem, 2006; Abebe et al., 2015) and 90\%-99.999\% of bacteria (Brown and Sobsey, 2010) and thus have been evaluated for efficacy in reducing rates of diarrheal and other waterborne diseases (Clasen et al., 2004; Morris et al., 2018). Unlike chlorine or thermal disinfection, CWFs do not significantly change the taste or temperature of the water. They are also very effective at reducing the turbidity of the water (Abebe et al., 2016). With proper care as suggested by manufacturers in the user manual, commercial ceramic pot filters, one of the most popular CWFs in the developing countries, have a potential service life of up to 5 years to effectively remove pathogens from raw water without the need for an external energy source or consumable supplies (The Ceramics Manufacturing Working Group, 2011). So far, locally produced CWFs have been successfully applied in more than 20 developing countries (e.g., Cambodia, Guatemala) to improve the drinking water quality (Rayner et al., 2013a). It was estimated that more than 4 million people worldwide used CWFs to prepare daily safe drinking water, which contributed to public health, social and economic benefits (van der Laan et al., 2014).

At the same time, CWFs have some disadvantages that limit their application. First, the relatively low water filtration rates have limited their use. Improved CWF designs that can simultaneously achieve both high flow rate and effective bacterial removal are desirable but remain a great challenge. In addition, CWFs often have limited capability of removing contaminants such as viruses and chemical pollutants (Yang et al., 2019a).

Although the CWF technology has been gaining growing research attentions and witnessing a wide application during the past decades, there have been few critical reviews on the progress of this technology. The objective of this account is to provide 1) a concise summary of the progress of recent CWF research and application with a particular focus on the critical factors and processes that are closely related to CWF performance, and 2) an overview of challenges and opportunities for further improvement for CWF as a POU water treatment technology in developing areas.

\section{Critical factors for CWF performance}

CWFs are fabricated from a mixture of clay and combustible materials (e.g., rice husks or sawdust) referred as burn-out materials. Filter porous structure is created as a result of the burn-out during the firing process. As shown in Fig. 2, fabrication of conventional ceramic filter includes raw material selection and processing, mixing and pressing, drying and firing, silver application, as well as quality testing. In this section, we focus on the processes whose effects on filter effectiveness have been documented by published reports and peer-reviewed references.

\subsection{Raw material selection}

\subsubsection{Clay source}

Clay is the skeleton element of CWF, and its quality and characteristics directly influence filter quality. Earthenware clay is most suitable for ceramic filter production due to its porosity, availability, and low temperature needed for vitrification. In practice, clay physical properties (e.g., shrinkage, plasticity, workability), the persistent availability of clay source, and the leachability of heavy metals/ inorganic materials are some key parameters to be considered for clay source selection (The Ceramics Manufacturing Working Group, 2011). Details for clay source test, selection and handling have been described in the instruction manuals of Potters for Peace (PFP) and Resource Development International (RDI) (Hagan et al., 2009; The Ceramics Manufacturing Working Group, 2011). Although clay does not create pore structure directly, Oyanedel-Craver and Smith (2008) found that filters made from different clay sources showed varied porosity, hydraulic conductivity and bacterial removal efficiency. A recent study suggested that high content of sand-rich clay may contribute to the decrease of mean pore size of CWF and thus potentially influence filter flow rate and bacterial removal efficacy (Youmoue et al., 2017). Additionally, the inclusion of diatomaceous earth and $\mathrm{MgO}$ components in the CWFs were found to be beneficial for viral removal (Michen et al., 2012; Michen et al., 2013), suggesting that clay composition may also have some influence on filter performance.

\subsubsection{Organic combustible material}

In the CWF manufacturing process, sieved organic combustible material, also known as burn-out material, is mixed with raw clay for the purpose of creating a paste which is subsequently pressed into various shaped filters. The organic combustible materials are usually burnt out during the firing process to create porous structure that serve as both flow paths for water passage and reaction sites for the removal of various contaminants such as bacteria and virus. The combustible material thus has been identified as a critical parameter on the performance of CWFs. Sawdust and rice husk are the most common combustible materials used in manufacturing CWFs and a global-wide survey reported that 17 in $18 \mathrm{CWF}$ production factories used sawdust or rice husk as the combustible material (Rayner et al., 2013a). In addition, coffee husks, peanut husks and other organic materials that can be pulverized to a suitable size can also be used as combustible materials, depending on their cost and local availability. According to previous laboratory and field studies, the size and amount of combustible material have a strong influence on the filter performance (Kallman et al., 

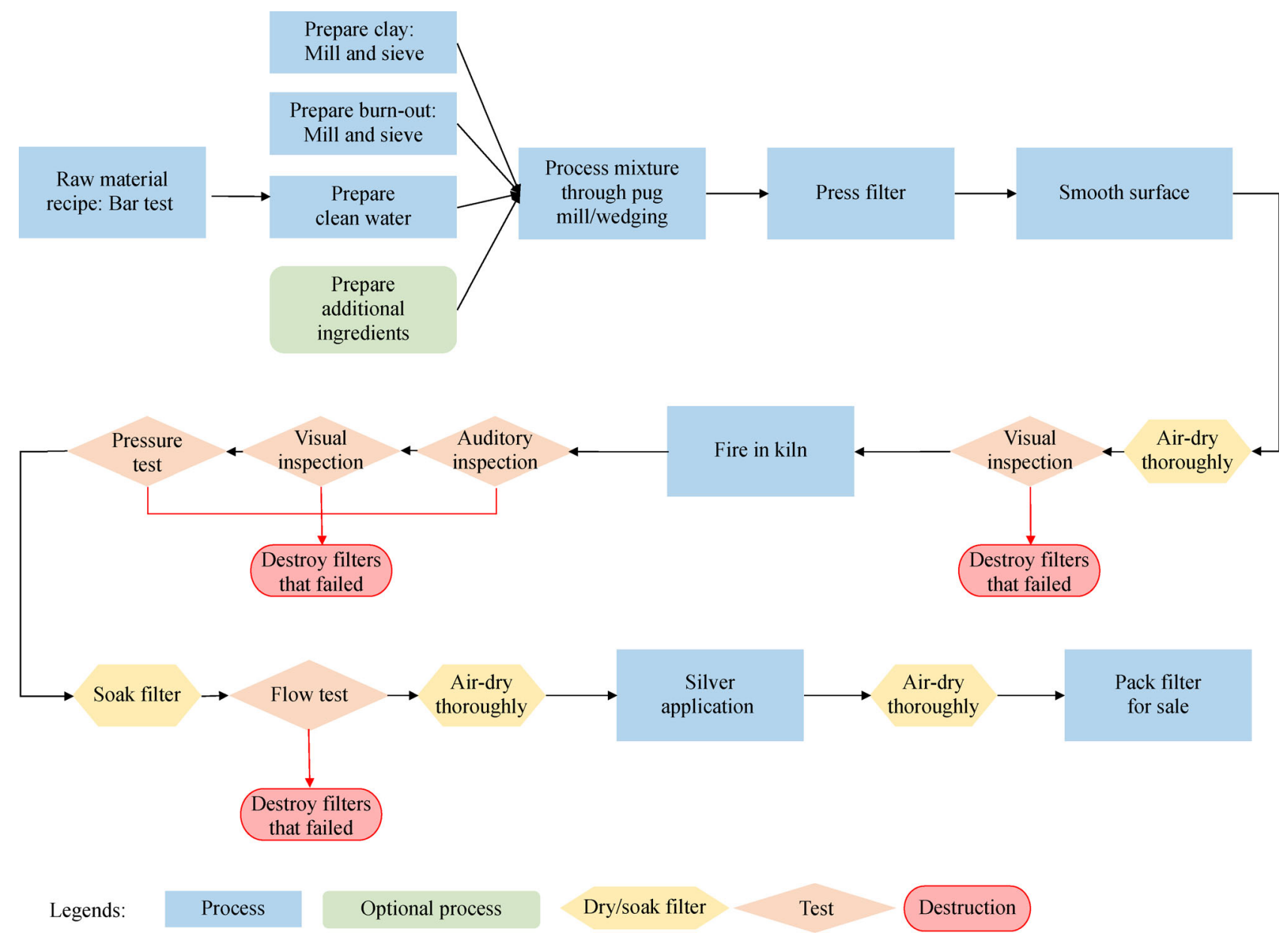

Fig. 2 Ceramic water filter production flow chart. It was re-drawn based on the Ceramics Manufacturing Working Group (2011).

2011; van der Laan et al., 2014; Soppe et al., 2015; Rayner et al., 2017; Van Halem et al., 2017). For example, Van Halem et al. (2017) produced pot filters with a higher flow rate (2-6 times as regular pot filters) by increasing the rice husk content from $24 \%$ to $31 \%$ (wt. $\%$ of dry clay mixture). Combustible material with a larger particle size has also been reported to introduce larger pore sizes of the resulting CWF, which could facilitate a higher flow rate but often resulted in lower microbial removal efficacy (Soppe et al., 2015; Rayner et al., 2017).

\subsection{Firing process}

The firing process of CWFs generally consists of seven stages that include water smoking $\left(20^{\circ} \mathrm{C}-120^{\circ} \mathrm{C}\right)$, decomposition $\left(120^{\circ} \mathrm{C}-350^{\circ} \mathrm{C}\right)$, burn-out combusts $\left(350^{\circ} \mathrm{C}-450\right.$ $\left.{ }^{\circ} \mathrm{C}\right)$, ceramic change $\left(350^{\circ} \mathrm{C}-700^{\circ} \mathrm{C}\right)$, carbon burns out $\left(700^{\circ} \mathrm{C}-900^{\circ} \mathrm{C}\right)$ and vitrification $\left(<1000^{\circ} \mathrm{C}\right)$ (The Ceramics Manufacturing Working Group, 2011). A detailed recommendation of kiln construction and firing variables has been provided by The Ceramics Manufacturing Working Group (2011). Soppe et al. (2015) observed increased flow rate and slightly decreased microbe removal efficiency when the maximum firing temperature increased from $800^{\circ} \mathrm{C}$ to $950{ }^{\circ} \mathrm{C}$, which may be attributed to the small increase of filter pore size with increasing maximum firing temperature. Additionally, the incomplete combustion of the organic materials could lead to the production of substances such as black carbon cores inside the filter during the firing of commercial CWFs (The Ceramics Manufacturing Working Group, 2011; Goodwin et al., 2017). Currently, black CWF was reported to be fired in a reductive atmosphere to improve its virus removal performance (Guerrero-Latorre et al., 2019). The potential impact of the firing atmosphere on the performance of the resulting CWFs, especially for the removal of contaminants other than pathogens, may warrant further investigation in the future.

\subsection{Silver impregnation}

Silver is typically applied as an antimicrobial agent to modify commercial CWFs after the firing process to enhance the bacterial removal efficiency, and to prevent biofilm growth and recontamination after treatment. The 
primary mechanisms for bacterial removal using silverimpregnated CWFs include both physical filtration (e.g., size exclusion and straining) and chemical inactivation (silver disinfection), and silver antibiotic activity occurs during both the filtration process and the subsequent water storage in the receptacle (van der Laan et al., 2014). Previous studies reported that silver-impregnated CWFs could exhibit up to $5 \log$ reduction value (LRV) of bacterial removal (i.e., 99.999\%), while CWFs before silver impregnation could only reach an average of 2 LRV (i.e., 99\%) of bacterial removal (Oyanedel-Craver and Smith, 2008; Rayner et al., 2013b). The amount of silver applied has been found to strongly influence the bacterial removal efficiency, and thus the silver dose needs to be delicately controlled so that it is sufficient to ensure effective disinfection for a long time (Ren and Smith, 2013). Therefore, understanding of factors governing the silver retention and release behavior from CWFs surface is crucial to evaluate the performance and lifespan of silverimpregnated CWFs.

Several factors have been reported to influence the silver release behavior, including silver impregnation method, silver type, and source water chemistry (Rayner et al., 2013b; Ren and Smith, 2013; van der Laan et al., 2014; Mittelman et al., 2015; Sullivan et al., 2017; Lyon-Marion et al., 2018). Ren and Smith (2013) compared three methods to modify CWFs with silver nanoparticles (nAg) and found that the fire-in method where $\mathrm{nAg}$ was applied before firing significantly improved silver retention and decreased its release from CWFs, compared to the paint-on and dipping methods, both of which were introducing $\mathrm{nAg}$ after the ceramic firing process. A few previous studies reported that silver release from filters coated with silver nitrate $\left(\mathrm{Ag}^{+}\right)$was greater than those coated with $\mathrm{nAg}$, and the effluent silver concentration was dependent on the amount of silver applied (Rayner et al., 2013b; Sullivan et al., 2017). Additionally, source water chemistry, including ionic strength, $\mathrm{pH}$, ion valence, the presence of natural organic matter and free chlorine, has been found to influence silver release (Rayner et al., 2013b; Mittelman et al., 2015; Sullivan et al., 2017; Lyon-Marion et al., 2018). Laboratory studies reported that the concentrations of leached silver in treated solutions were below the drinking water standard $(0.1 \mathrm{mg} / \mathrm{L})$ (Rayner et al., 2013b; Mittelman et al., 2015). In practice, new silver-impregnated CWFs are suggested by manufacturers to rinse with 2-3 pot full of water before use, which could lower the silver concentration in the effluent to levels below $0.1 \mathrm{mg} /$ L (The Ceramics Manufacturing Working Group, 2011). Although silver impregnation shows improved bacterial removal efficiency, there are concerns about the cost associated with the silver application, and the relatively short service life of conventional filters (3-5 years) because the filters would become less effective when the impregnated silver is depleted (Lantagne, 2001; Bielefeldt et al., 2009).

\subsection{Source water quality}

As CWFs are being used on a global scale for the production of safe drinking water for both household and/ or small community, the source water quality can be substantially varied between different applications. While variations in the performance of CWFs have been reported from different areas or/and filter factories, these variations were primarily attributed to the differences in local materials and filter fabrication process, and the role of source water quality remains largely unknown. Among various water quality factors, only limited studies have focused on turbidity and reported its negative impact on CWF performance (water production and/or flow rate) due to pore blocking (Salvinelli and Elmore, 2015; Salvinelli et al., 2016). For silver impregnated CWFs, both physical filtration and silver disinfection are considered important pathogen removal mechanisms. Although water chemistry parameters (e.g., pH, ionic strength, presence of various ions) may theoretically have relatively limited influence on pathogen removal via physical filtration, they can significantly affect the silver release behaviors, and thus affect the filter performance and service lifespan. Detailed and long-term laboratory and field studies are needed to further explore the performance of CWFs in various water sources.

\section{Challenges and opportunities}

\subsection{Flow rate versus microbial removal efficiency}

Flow rate and microbial removal efficiency are two performance indicators for CWFs. Filters that can maintain both high flow rates and effective microbial removal would be particularly desirable for end users. As discussed in the previous section, numerous attempts have been taken to improve CWF fabrication (e.g., combustible material processing) for the development of effective and fastflow CWFs. Table 2 summarizes the flow rate and microbial removal efficiency of CWFs reported in previous laboratory- and field-scale investigations. To allow for the comparison of CWFs made in different shapes, the reported flow rates were converted to the "equivalent" flow rates of a full-size ceramic pot filter with a frustum shape, based on the hydraulic method used in our previous study (Yang et al., 2020). So far, the ceramic pot filter design (Fig. 1(c)), one of the most popular CWFs applied in developing countries, can achieve a balance of 1-3 L/h flow rate and $\sim 2$ LRV bacterial removal without silver impregnation ( $\sim 4$ LRV after silver impregnation). For a typical household size with 5 persons, at least $10 \mathrm{~L}$ of safe drinking water would be needed on a daily basis (Ren et al., 2013). However, as sediment and particles clog the filter pores, the flow rate decreases. Scrubbing the filter surface provides a temporary benefit but does not prevent 
Table 2 Flow rate and bacterial removal efficiency of reported CWFs

\begin{tabular}{|c|c|c|c|c|c|}
\hline Reference/ source & $\begin{array}{c}\text { Laboratory/Field } \\
\text { work }\end{array}$ & $\begin{array}{l}\text { Flow rate } \\
(\mathrm{L} / \mathrm{h})\end{array}$ & $\begin{array}{l}\text { Microbial removal } \\
\left(\mathrm{LRV}^{\mathrm{b})}\right)\end{array}$ & Porosity & $\begin{array}{l}\text { Average pore size } \\
\qquad(\mu \mathrm{m})^{\mathrm{c})}\end{array}$ \\
\hline \multirow[t]{2}{*}{ Yang et al. (2020) } & \multirow[t]{2}{*}{ Laboratory } & $5.1-6.4$ & 4.5 & 0.22 & 1.22 \\
\hline & & $12.5-15.4$ & 2.1 & 0.24 & 1.24 \\
\hline \multirow[t]{3}{*}{$\begin{array}{l}\text { Oyanedel-Craver and Smith } \\
\text { (2008) }\end{array}$} & \multirow[t]{3}{*}{ Laboratory } & $\sim 2.6$ & $\begin{array}{l}3.0 \text { (w/o Ag coating) } \\
4.0 \text { (w/o Ag coating) }\end{array}$ & 0.37 & 14.3 \\
\hline & & $\sim 1.7$ & $\begin{array}{l}2.9 \text { (w/o Ag coating) } \\
3.2 \text { (w/o Ag coating) }\end{array}$ & 0.42 & 2.0 \\
\hline & & $\sim 0.61$ & $\begin{array}{l}3.4 \text { (w/o Ag coating) } \\
3.8 \text { (w/o Ag coating) }\end{array}$ & 0.39 & 8.2 \\
\hline Bielefeldt et al. (2009) & Laboratory/Field & $0.8-1.9$ & $\begin{array}{l}2.2-3.8 \text { (w/o Ag coating) } \\
3.2-4.2 \text { (w/o Ag coating) }\end{array}$ & \multicolumn{2}{|c|}{ Not reported } \\
\hline \multirow[t]{2}{*}{ van der Laan et al. (2014) } & \multirow[t]{2}{*}{ Field } & $5.5-21.0$ & $\sim 1$ (w/o Ag coating) & \multirow{2}{*}{\multicolumn{2}{|c|}{ Not reported }} \\
\hline & & 2.55 & 2.5 (w/o Ag coating) & & \\
\hline Van Halem et al. (2017) & Field & $5-20$ & $\sim 1.0$ (w/o Ag coating) & \multicolumn{2}{|c|}{ Not reported } \\
\hline Soppe et al. (2015) & Laboratory/Filed & $7-23$ & $2.1-2.9$ (w/o Ag coating) & \multicolumn{2}{|c|}{ Not reported } \\
\hline $\mathrm{PFP}^{\mathrm{d})}$ & Field & $1-3$ & $\sim 2$ (w/o Ag coating) & \multirow{2}{*}{\multicolumn{2}{|c|}{$\begin{array}{l}\text { Various from factory to factory } \\
\text { Various from factory to factory }\end{array}$}} \\
\hline $\mathrm{RDIC}^{\mathrm{e})}$ & Field & $1.8-2.5$ & $\sim 2$ (w/o Ag coating) & & \\
\hline
\end{tabular}

Note: a) Flow rate was adjusted for disk bottom diameter and water head to the full size of pot (Fig. 1(c)). Detail for adjustment can be found in Yang et al. (2020); b) LRV, $\log$ reduction value;c) Average pore diameter was obtained by the pore size distribution data measured by mercury intrusion porosimetry (MIP); d) Pottery for peace, a US-based non-profit working on ceramic water filter; e) Resource Development International-Cambodia, a non-profit working on ceramic water filter.

long-term clogging. The development of filters that can achieve a higher flow rate while maintaining effective microbial removal remains a challenge. Instigations into manufacturing parameters that can be modified to achieve both high flow rate and effective microbial removal are needed.

Pore size of CWFs is considered a critical parameter that can affect both flow rate and microbial removal efficiency (Soppe et al., 2015; Youmoue et al., 2017). CWFs were prepared using three combustible materials that include irregularly shaped rice husk, spherical/oval shaped starch and tubular shaped recycled paper fiber in our recent study (Yang et al., 2020). Because of the different shapes of combustible materials, the fabricated CWFs had varied pore size distribution patterns, resulting in substantially different flow rates and bacterial removal efficiencies. Particularly, filters prepared using recycled paper fiber showed improved performance with regards to both flow rate and bacterial removal. The best-performed filters (no silver coating) exhibited (1) a fast equivalent flow rate of $13.9 \mathrm{~L} / \mathrm{h}$ while maintaining a $>2 \log$ bacterial removal efficiency (>99\%), or (2) >4 $\log$ bacterial removal efficiency (>99.99\%) with an equivalent flow rate of 5.9 $\mathrm{L} / \mathrm{h}$, by simply tuning the amount of the recycled paper fibers to $20 \%$ and $15 \%$ (i.e., with fiber-to-clay ratios of 20\%:80\% and 15\%:85\%), respectively. The improved performance of filters prepared using recycled paper fibers could be attributed to the unique pore size distribution pattern that consists a good balance of both small and medium to large pores. Based on the classic HagenPoiseuille law, medium to large pores are required to reach a high flow rate; meanwhile, the presence of a sufficient number of small pores is essential for achieving a satisfactory bacterial removal efficiency. Results suggested that fibrous materials like recycled paper fiber may potentially be used as effective combustible materials for CWF fabrication to create balanced and interconnected pore structure. Meanwhile, Soppe et al. (2015) observed that average flow rate of CWFs could be increased by using larger quantities of rice husks but without reducing the bacterial removal effectiveness. Further information and analysis of the pore size distribution of these filters are needed to explore the critical factors for improved CWFs.

An improved understanding of key factors that affect and control the pore size distribution can provide important insights into guiding the design of CWFs with both high flow rate and bacterial removal. In an initial attempt, a semiquantitative model was developed to explain the role of pore size distribution on the design of optimal CWFs that can balance effective microbial removal and adequate flow rate (Yang et al., 2020). With further information of pore network within porous ceramic using advanced characterization and 3-dimensional imaging techniques, development of more sophisticated pore-scale mathematical and numeric models in the future can be beneficial to direct the design of ceramic filters with controlled pore size distribution and improved performance. In addition, manufacturing parameters other than combustible material can affect the pore size distribution of CWFs. For instance, Oyanedel-Craver and Smith observed different pore size distributions for CWFs fabricated using three different sourced clay materials, and filters prepared from redart clay 
had most abundance of small pores and thus highest bacterial removal efficiency (Oyanedel-Craver and Smith, 2008). A comprehensive investigation should be performed in the future to determine the impact of individual manufacturing parameters as well as their combined effect on the pore size distribution of ceramic filters. It also should be mentioned that the flow rate of CWFs may decrease after extended use in the field because of sediment and/or particle clogging. Thus, the long-term performance of ceramic filters prepared using improved recipes should be evaluated under settings relevant to practical applications.

\subsection{Removal of various classes of contaminants}

Conventional CWFs are designed to primarily target the removal of microbial pollutants with relatively large sizes (e.g., bacteria, protozoa). Pore sizes of conventional CWFs are typically in the range of 0.1-100 $\mu \mathrm{m}$ (Oyanedel-Craver and Smith, 2008; Brown and Sobsey, 2010), and thus they are not able to retain small-sized pathogens (e.g., virus) and commonly-found chemical pollutants (e.g., arsenic, fluoride, chromate) through physical filtration. Additionally, because of the negatively charged ceramic surface, CWFs with and without silver coating generally exhibit low affinity with virus and negatively- and non-charged chemical pollutants, resulting in negligible capture of these pollutants through adsorption as well. For example, previous studies reported that CWFs only had viral removal efficiencies in the range of 0.21 to $1.6 \mathrm{LRV}$ in long-term testing (Brown and Sobsey, 2010; Salsali et al., 2011; van der Laan et al., 2014), with no significant differences between silver-impregnated and non-impregnated CWFs (van der Laan et al., 2014). The low removal efficiency for virus and various chemical pollutants represents a major challenge for conventional CWFs.

Chemical pollutants are generally removed through the interaction (e.g., adsorption, surface precipitation) with surface of (modified) CWFs. To improve the removal of chemical pollutants, a practical approach is to modify the ceramic surface with desired coatings to enhance the affinity with the target pollutants. For instance, ceramic disk filter modified with ferric iron was developed to improve arsenic removal, and the filter performance was strongly affected by the ferric iron loading (Robbins et al., 2014). Recently, lanthanum (La), an abundant rare earth element with relatively low cost, was applied in our study as a novel and effective coating for ceramic materials to target the removal of negatively-charged arsenate $(\mathrm{As}(\mathrm{V}))$ and non-charged arsenite (As(III)) (Yang et al., 2019a). The La-coated ceramic material showed substantially enhanced capture of both $\mathrm{As}(\mathrm{V})$ and $\mathrm{As}(\mathrm{III})$ with the sorption capacities of 24.8 and $10.9 \mathrm{mg} / \mathrm{g}$, respectively. On the contrary, negligible adsorption of $\mathrm{As}(\mathrm{V})$ or $\mathrm{As}(\mathrm{III})$ was observed for bare ceramic material without La coating. Furthermore, a prototype La-coated ceramic disk filter could efficiently treat $\sim 14500$ and 3200 pore volumes of solutions highly contaminated with $\mathrm{As}(\mathrm{V})$ and $\mathrm{As}(\mathrm{III})$ $(\sim 125 \mu \mathrm{g} / \mathrm{L})$ below the drinking water standard $(10 \mu \mathrm{g} / \mathrm{L})$, respectively. The improved removal of $\mathrm{As}(\mathrm{V})$ and $\mathrm{As}(\mathrm{III})$ can be attributed to the formation of $\mathrm{LaAsO}_{4}$ surface precipitates and $\mathrm{La}$ involved inner-sphere surface complexes, respectively. Notably, the interaction between chemical pollutants and La coating strongly depends on the chemical composition and properties of the La coating, which can be controlled by the coating process. Thus, a delicate control of the La coating temperature is critical to obtaining optimal La components that favor the removal of various chemical pollutants (Yang et al., 2019b).

Since most viruses hold negative charges in natural aquatic environments ( $\mathrm{pH} 5-8$ ), modification of ceramic surface with positively charged chemical coatings has been applied to promote virus removal via enhanced electrostatic interaction (Table 3). Michen et al. (2013) reported that ceramic filters amended with $\mathrm{MgO}$ increased the removal of bacteriophages MS2 and PhiX174 by up to 4 LRV, while the filter performance decreased sharply after 2000 pore volumes of treatment. Wegmann et al (2018 a, b). found that modification of ceramic microfilters with $\mathrm{Zr}$ $(\mathrm{OH})_{x}$ and $\mathrm{Y}_{2} \mathrm{O}_{3}$ greatly increased the isoelectric point $\left(\mathrm{pH}_{\mathrm{IEP}}\right)$ of the filters from $<3.1$ to $5.5-9$ and $8-10$, respectively. Thus, the $\mathrm{Zr}(\mathrm{OH})_{x^{-}}$and $\mathrm{Y}_{2} \mathrm{O}_{3}$-modified ceramic filters showed remarkably increased removal efficiency of MS2 (up to 7 LRV). Meanwhile, the authors observed that the presence of humic acid negatively impact the filter performance, and the virus removal efficiency also significantly decreased after extended operation (Wegmann et al., 2008b). In addition to virus removal, it is worth mentioning that some novel coatings such as nano $\mathrm{TiO}_{2}$ and nano $\mathrm{ZnO}$ have also been applied as alternative antimicrobial agents to silver for ceramic modification to improve the cost-effectiveness of bacterial removal in the laboratory-scaled studies (Lucier et al., 2017; He et al., 2018; Huang et al., 2018).

As more and more low-cost, environmentally benign and novel coatings are being explored for ceramic surface modification, it holds promises to develop modified CWFs with improved performance for the removal of various small-sized chemical and microbial pollutants. Since the properties of surface coatings and thus their interaction with pollutants are strongly influenced by water chemistry parameters, further investigations are required to determine the long-term filter performance in both laboratory and field scales under various source waters. The safety and leaching behavior of the novel coatings should also be carefully evaluated before field application.

\section{Conclusions}

CWFs, produced from local-sourced clay and combustible material is an affordable, effective, low-maintenance and 
Table 3 Studies exploring CWFs surface modification besides silver impregnation

\begin{tabular}{|c|c|c|c|c|}
\hline $\begin{array}{l}\text { Modification } \\
\text { component }\end{array}$ & Modification method & Target contaminants & Removal efficacy/capacity ${ }^{\text {a) }}$ & References \\
\hline$\overline{\text { Nano } \mathrm{TiO}_{2}}$ & Painted-on ${ }^{b)}$ & Escherichia coli & $>90 \%$ & He et al. (2018) \\
\hline $\mathrm{ZnO}$ & Painted-on & Escherichia coli & 2.19-2.97 LRV & Huang et al. (2018) \\
\hline $\mathrm{TPA}^{\mathrm{c})}$ & Painted-on & Escherichia coli & $\begin{array}{c}\text { 6.24 LRV } \\
\text { (raw filter } 4.34 \mathrm{LRV} \text { ) }\end{array}$ & $\begin{array}{l}\text { Zhang and Oyanedel-Craver } \\
\text { (2013) }\end{array}$ \\
\hline \multirow[t]{2}{*}{ Iron oxide } & $\begin{array}{l}\text { Submersed in } \mathrm{Fe}^{3+} \text { solution } \rightarrow \text { baked } \\
\quad \text { at } 110^{\circ} \mathrm{C}(4 \mathrm{~h}) \rightarrow 550^{\circ} \mathrm{C}(3 \mathrm{~h})\end{array}$ & $\begin{array}{l}\text { Arsenite/ } \\
\text { As(III) }\end{array}$ & $\begin{array}{l}\text { Treating } 49-1619 \text { bed volumes of arsenic- } \\
\text { contaminated solution under } 10 \mu \mathrm{g} / \mathrm{L}\end{array}$ & Robbins et al. (2014) \\
\hline & & $\begin{array}{l}\text { Arsenate/ } \\
\operatorname{As}(\mathrm{V})\end{array}$ & & \\
\hline \multirow[t]{4}{*}{$\begin{array}{l}\text { Lanthanum } \\
\text { components }\end{array}$} & $\begin{array}{l}\text { Submersed in } \mathrm{La}^{3+} \text { solutio } \rightarrow \text { ther- } \\
\text { mally treated for } 3 \mathrm{~h}\end{array}$ & $\begin{array}{l}\text { Arsenite/ } \\
\text { As(III) }\end{array}$ & $\begin{array}{l}\text { Treating } \sim 3200 \text { pore volumes of } \mathrm{As}(\mathrm{III})- \\
\text { contaminated solution under } 10 \mu \mathrm{g} / \mathrm{L}\end{array}$ & Yang et al. $(2019 a, b)$ \\
\hline & & $\begin{array}{l}\text { Arsenate/ } \\
\operatorname{As}(\mathrm{V})\end{array}$ & $\begin{array}{l}\text { Treating } \sim 14500 \text { pore volumes of } \mathrm{As}(\mathrm{V})- \\
\text { contaminated solution under } 10 \mu \mathrm{g} / \mathrm{L}\end{array}$ & \\
\hline & & $\begin{array}{l}\text { Chromate/ } \\
\text { Cr(VI) }\end{array}$ & $13 \mathrm{mg} / \mathrm{g}$ & \\
\hline & & Virus (MS2) & $>5 \mathrm{LRV}$ & \\
\hline $\mathrm{Y}_{2} \mathrm{O}_{3}$ & $\begin{array}{c}\text { Submersed in } \mathrm{Y}_{2} \mathrm{O}_{3} \text { colloids } \rightarrow \text { dried } \\
\text { at } 80^{\circ} \mathrm{C}(12 \mathrm{~h}) \rightarrow \text { calcined at } 500^{\circ} \mathrm{C}- \\
1040^{\circ} \mathrm{C}(1 \mathrm{~h})\end{array}$ & virus (MS2) & Up to $6.5 \mathrm{LRV}$ & Wegmann et al. (2008a) \\
\hline $\mathrm{Zr}(\mathrm{OH})_{x}$ & $\begin{array}{l}\text { Submersed in } \mathrm{Zr}(\mathrm{OH})_{x} \text { colloids } \rightarrow \\
\text { dried at } 150^{\circ} \mathrm{C}(12 \mathrm{~h}) \rightarrow \text { calcined at } \\
250 / 300 / 400^{\circ} \mathrm{C}(1 \mathrm{~h})\end{array}$ & virus (MS2) & $\begin{array}{l}\text { 6.2-6.6 LRV (pH5) } \\
\text { 4.0-6.9 LRV (pH7) } \\
\text { 3.7-7.4 LRV (pH9) }\end{array}$ & Wegmann et al. (2008b) \\
\hline $\mathrm{MgO}$ & Fired-in ${ }^{\text {d) }}$ & virus (MS2, PhiX174) & $\begin{array}{l}0.3-4.7 \text { LRV (MS2) } \\
0-4 \text { LRV (PhiX174) }\end{array}$ & Michen et al. (2013) \\
\hline
\end{tabular}

Note: a) Removal efficacy/capacity: removal capacity was used to indicate CWFs performance for chemical pollutant removal; b) Painted-on: using a paint brush to paint the coating chemical solution to filter surface, then air-dried; c) TPA: poly (trihydroxysilyl) propyldimethyloctadecyl ammonium chloride; d) Fired-in: coating chemical was added to clay mixture before firing.

sustainable technology appropriate for POU household water treatment in developing areas. This account focuses on the critical factors for CWFs performance, including manufacturing processes and source water quality. Two technical challenges that limit the further application of CWFs are discussed in detail, including simultaneous improvement of filter flow rate and bacterial removal, and efficient removal of various chemical and microbial pollutants. Great efforts from researchers and CWFs manufacturers have been taken to (1) improve CWFs with both high flow rate and effective bacterial removal by optimizing pore properties during the filter manufacturing processes, as well as (2) enhance CWFs removal efficacy of various waterborne contaminants by novel chemical modification on ceramic surface. According to the brief summary of progress for CWFs research and application in last decades, including our research, several future research directions are proposed to guide the design, manufacture, and application of improved CWFs for POU water treatment in developing countries.

Acknowledgements This work was supported by the University of Wisconsin Applied Research Grant (MIL111691) and the University of
Wisconsin Milwaukee Catalyst Grant (MIL113501). The authors declare no competing financial interest.

Open Access This article is licensed under a Creative Commons Attribution 4.0 International License, which permits use, sharing, adaptation, distribution and reproduction in any medium or format, as long as you give appropriate credit to the original author(s) and the source, provide a link to the Creative Commons licence, and indicate if changes were made. The images or other third party material in this article are included in the article's Creative Commons licence, unless indicated otherwise in a credit line to the material. If material is not included in the article's Creative Commons licence and your intended use is not permitted by statutory regulation or exceeds the permitted use, you will need to obtain permission directly from the copyright holder. To view a copy of this licence, visit http://creativecommons.org/licenses/by/4.0/.

\section{References}

Abebe L S, Chen X, Sobsey M D (2016). Chitosan coagulation to improve microbial and turbidity removal by ceramic water filtration for household drinking water treatment. International Journal of Environmental Research and Public Health, 13(3): 269-279

Abebe L S, Su Y H, Guerrant R L, Swami N S, Smith J A (2015). Pointof-use removal of Cryptosporidium Parvum from water: Independent effects of disinfection by silver nanoparticles and silver ions and by physical filtration in ceramic porous media. Environmental Science 
\& Technology, 49(21): 12958-12967

Bielefeldt A R, Kowalski K, Summers R S (2009). Bacterial treatment effectiveness of point-of-use ceramic water filters. Water Research, 43(14): 3559-3565

Brown J, Sobsey M D (2010). Microbiological effectiveness of locally produced ceramic filters for drinking water treatment in Cambodia. Journal of Water and Health, 8(1): 1-10

Clasen T F, Alexander K T, Sinclair D, Boisson S, Peletz R, Chang H H, Majorin F, Cairncross S (2015). Interventions to improve water quality for preventing diarrhoea. Cochrane Database of Systematic Reviews,

Clasen T F, Brown J, Collin S, Suntura O, Cairncross S (2004). Reducing diarrhea through the use of household-based ceramic water filters: A randomized, controlled trial in rural Bolivia. American Journal of Tropical Medicine and Hygiene, 70(6): 651-657

Geremew A, Mengistie B, Alemayehu E, Lantagne D S, Mellor J, Sahilu G (2018). Point-of-use water chlorination among urban and rural households with under-five-year children: A comparative study in Kersa Health and Demographic Surveillance Site, Eastern Ethiopia. Journal of Water, Sanitation, and Hygiene for Development, 8(3): $468-480$

Goodwin J Y, Elmore A C, Salvinelli C, Reidmeyer M R (2017). An optical method for characterizing carbon content in ceramic pot filters. Journal of Water and Health, 15(4): 536-544

Guerrero-Latorre L, Balseca-Enriquez P, Moyota-Tello C, BravoCamino R, Davila-Chavez S, Bonifaz-Arcos E, Romero-Carpio B, Chico-Teran M (2019). Performance of black ceramic water filters and their implementation in rural Ecuador. Journal of Water, Sanitation, and Hygiene for Development, 9(4): 694-702

Hagan J,Harley N, Hughes R, Chouhan A, Pointing D, Sampson M, Saom V, Smith K (2009). Resource Developing International-Cambodia ceramic water filter handbook. Phnom Penh, Cambodia: Engnieers Without Borders Australia

He Y, Huang G, An C, Huang J, Zhang P, Chen X, Xin X (2018). Reduction of Escherichia coli using ceramic disk filter decorated by nano- $\mathrm{TiO}_{2}$ : A low-cost solution for household water purification. Science of the Total Environment, 616-617: 1628-1637

Huang J, Huang G H, An C J, He Y, Yao Y, Zhang P, Shen J (2018). Performance of ceramic disk filter coated with nano $\mathrm{ZnO}$ for removing Escherichia coli from water in small rural and remote communities of developing regions. Environmental Pollution, 238: 52-62

Kallman E N, Oyanedel-Craver V A, Smith J A (2011). Ceramic filters impregnated with silver nanoparticles for point-of-use water treatment in rural Guatemala. Journal of Environmental Engineering, 137 (6): 407-415

Lantagne D S (2001). Investigation of the potters for peace colloidal silver impregnated ceramic filter Report 2: Field Investigations

Lucier K J, Dickson-Anderson S E, Schuster-Wallace C J (2017). Effectiveness of silver and copper infused ceramic drinking water filters in reducing microbiological contaminants. Journal of Water Supply: Research \& Technology- Aqua, 66(7): 528-536

Lyon-Marion B A, Mittelman A M, Rayner J, Lantagne D S, Pennell K D (2018). Impact of chlorination on silver elution from ceramic water filters. Water Research, 142: 471-479

Michen B, Fritsch J, Aneziris C, Graule T (2013). Improved virus removal in ceramic depth filters modified with $\mathrm{MgO}$. Environmental Science \& Technology, 47(3): 1526-1533

Michen B, Meder F, Rust A, Fritsch J, Aneziris C, Graule T (2012). Virus removal in ceramic depth filters based on diatomaceous earth. Environmental Science \& Technology, 46(2): 1170-1177

Mittelman A M, Lantagne D S, Rayner J, Pennell K D (2015). Silver dissolution and release from ceramic water filters. Environmental Science \& Technology, 49(14): 8515-8522

Morris J F, Murphy J, Fagerli K, Schneeberger C, Jaron P, Moke F, Juma J, Ochieng J B, Omore R, Roellig D, Xiao L, Priest J W, Narayanan J, Montgomery J M, Hill V, Mintz E, Ayers T L, O'reilly C E (2018). A randomized controlled trial to assess the impact of ceramic water filters on prevention of diarrhea and cryptosporidiosis in infants and young children-western Kenya, 2013. American Journal of Tropical Medicine and Hygiene, 98(5): 1260-1268

Murphy H M, Mcbean E A, Farahbakhsh K (2010). Nitrification, denitrification and ammonification in point-of-use biosand filters in rural Cambodia. Journal of Water and Health, 8(4): 803-817

Oyanedel-Craver V A, Smith J A (2008). Sustainable colloidal-silverimpregnated ceramic filter for point-of-use water treatment. Environmental Science \& Technology, 42(3): 927-933

Peter-Varbanets M, Zurbrugg C, Swartz C, Pronk W (2009). Decentralized systems for potable water and the potential of membrane technology. Water Research, 43(2): 245-265

Rayner J, Luo X, Schubert J, Lennon P, Jellison K, Lantagne D (2017). The effects of input materials on ceramic water filter efficacy for household drinking water treatment. Water Science and Technology: Water Supply, 17(3): 859-869

Rayner J, Skinner B, Lantagne D (2013a). Current practices in manufacturing locally-made ceramic pot filters for water treatment in developing countries. Journal of Water, Sanitation, and Hygiene for Development, 3(2): 252-261

Rayner J, Zhang H, Schubert J, Lennon P, Lantagne D, Oyanedel-Craver V (2013b). Laboratory investigation into the effect of silver application on the bacterial removal efficacy of filter material for use on locally produced ceramic water filters for household drinking water treatment. ACS Sustainable Chemistry \& Engineering, 1(7): 737-745

Ren D, Colosi L M, Smith J A (2013). Evaluating the sustainability of ceramic filters for point-of-use drinking water treatment. Environmental Science \& Technology, 47(19): 11206-11213

Ren D J, Smith J A (2013). Retention and transport of silver nanoparticles in a ceramic porous medium used for point-of-use water treatment. Environmental Science \& Technology, 47(8): 38253832

Robbins E C, Guo J, Adams C D (2014). Removal of As(III) and As(V) in surface modified ceramic filters. Journal of Water, Sanitation, and Hygiene for Development, 4(2): 214-222

Salsali H, Mcbean E, Brunsting J (2011). Virus removal efficiency of Cambodian ceramic pot water purifiers. Journal of Water and Health, 9(2): 306-311

Salvinelli C, Elmore A C (2015). Assessment of the impact of water parameters on the flow rate of ceramic pot filters in a long-term experiment. Water Science and Technology: Water Supply, 15(6): $1425-1432$

Salvinelli C, Elmore A C, Reidmeyer M R, Drake K D, Ahmad K I 
(2016). Characterization of the relationship between ceramic pot filter water production and turbidity in source water. Water Research, 104: $28-33$

Sobsey M D, Stauber C E, Casanova L M, Brown J M, Elliott M A (2008). Point of use household drinking water filtration: A practical, effective solution for providing sustained access to safe drinking water in the developing world. Environmental Science \& Technology, 42(12): 4261-4267

Soppe A I A, Heijman S G J, Gensburger I, Shantz A, Van Halem D, Kroesbergen J, Wubbels G H, Smeets P (2015). Critical parameters in the production of ceramic pot filters for household water treatment in developing countries. Journal of Water and Health, 13(2): 587-599

Sullivan R K, Erickson M, Oyanedel-Craver V A (2017). Understanding the microbiological, organic and inorganic contaminant removal capacity of ceramic water filters doped with different silver nanoparticles. Environmental Science. Nano, 4(12): 2348-2355

The Ceramics Manufacturing Working Group (2011). Best practice recommendations for local manufacturing of ceramic pot filters for household water treatment. Atlant, GA, USA: Ceramics Manufacturing Working Group

van der Laan H, Van Halem D, Smeets P, Soppe A, Kroesbergen J, Wubbels G, Nederstigt J, Gensburger I, Heijman S (2014). Bacteria and virus removal effectiveness of ceramic pot filters with different silver applications in a long term experiment. Water Research, 51: $47-54$

Van Halem D (2006). Ceramic silver impregnated pot filters for household drinking water treatment in developing countries. Delft, Netherlands: Delft University of Technology

Van Halem D, Van Der Laan H, Soppe A, Heijman S (2017). High flow ceramic pot filters. Water Research, 124: 398-406

Wegmann M, Michen B, Graule T (2008a). Nanostructured surface modification of microporous ceramics for efficient virus filtration. Journal of the European Ceramic Society, 28(8): 1603-1612

Wegmann M, Michen B, Luxbacher T, Fritsch J, Graule T (2008b). Modification of ceramic microfilters with colloidal zirconia to promote the adsorption of viruses from water. Water Research, 42 (6-7): 1726-1734

World Health Organization (2017). Progress on drinking water sanitation and hygiene: 2017 update and SDG baselines. Geneva: World Health Organization

World Health Organization (2019a). Progress on household drinking water, sanitation and hygiene 2000-2017: Special focus on inequalities. Geneva: World Health Organization

World Health Organization (2019b). Drinking-water Fact sheet. New York: World Health Organization

Yang H, Min X, Xu S, Bender J, Wang Y (2020). Development of effective and fast-flow ceramic porous media for point-of-use water treatment: Effect of pore size distribution. ACS Sustainable Chemistry \& Engineering, 8(6): 2531-2539

Yang H, Min X, Xu S, Wang Y (2019a). Lanthanum(III)-coated ceramics as a promising material in point-of-use water treatment for arsenite and arsenate removal. ACS Sustainable Chemistry \& Engineering, 7 (10): 9220-9227

Yang H, Wang Y, Bender J, Xu S (2019b). Removal of arsenate and chromate by lanthanum-modified granular ceramic material: The critical role of coating temperature. Scientific Reports, 9(1): 7690

Youmoue M, Fongang R T T, Sofack J C, Kamseu E, Melo U C, Tonle I K, Leonelli C, Rossignol S (2017). Design of ceramic filters using clay/sawdust composites: Effect of pore network on the hydraulic permeability. Ceramics International, 43(5): 4496-4507

Zhang H Y, Oyanedel-Craver V (2013). Comparison of the bacterial removal performance of silver nanoparticles and a polymer based quaternary amine functiaonalized silsesquioxane coated point-of-use ceramic water filters. Journal of Hazardous Materials, 260: 272277

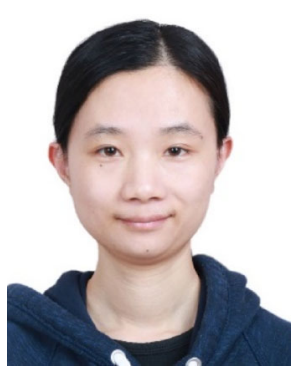

Haiyan Yang received her Ph.D. degree from Peking University and then worked as a postdoc fellow in Harbin Institute of Technology and University of WisconsinMilwaukee. She currently joined South China Normal University. Her research focuses on the sustainable point-of-use water treatment and the fate of colloidal contaminants.

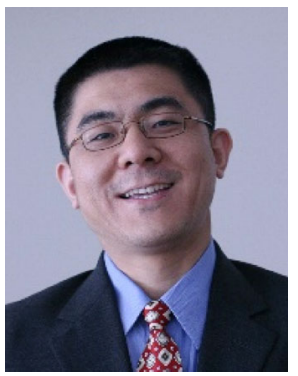

Shangping Xu received his B.S. degree from Peking University, and M.S and $\mathrm{Ph} . \mathrm{D}$. degrees from Princeton University. $\mathrm{He}$ is currently an Associate Professor at the University of Wisconsin - Milwaukee. His research interests include the transport of contaminant within the environment, effects of global climate change on water resources and the development of water treatment techniques.

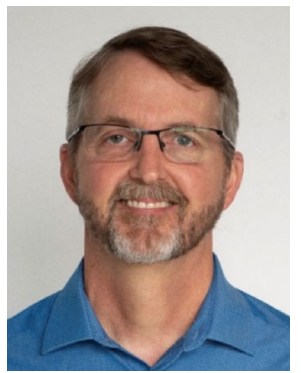

Derek E Chitwood has a B.S. degree in aerospace engineering and $\mathrm{Ph} . \mathrm{D}$. in environmental engineering, both from the University of Southern California. He spent 18 years working in rural southwest China. His research focus is studying mountain spring water quality and point of use water filters for rural peoples in developing communities.

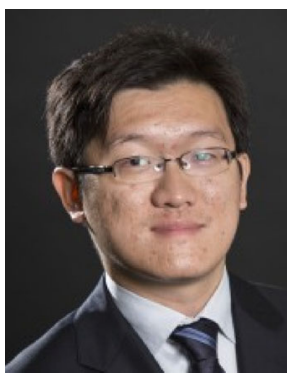

Yin Wang received his B.S. degree from Peking University, and M.S. and Ph.D. degrees from Washington University in St. Louis. He is currently an Assistant Professor at the University of Wisconsin Milwaukee. His research focuses on the development of efficient and sustainable solutions to address water-related grand challenges. 